\title{
The Distribution of Neurons Expressing Calcium-Permeable AMPA Receptors in the Superficial Laminae of the Spinal Cord Dorsal Horn
}

\author{
Holly S. Engelman, Thomas B. Allen, and Amy B. MacDermott \\ Department of Physiology and Cellular Biophysics and the Center for Neurobiology and Behavior, Columbia University, \\ New York, New York 10032
}

The superficial dorsal horn is a major site of termination of nociceptive primary afferents. Fast excitatory synaptic transmission in this region is mediated mainly by release of glutamate onto postsynaptic AMPA and NMDA receptors. NMDA receptors are known to be $\mathrm{Ca}^{2+}$-permeable and to provide synaptically localized $\mathrm{Ca}^{2+}$ signals that mediate short-term and long-term changes in synaptic strength. Less well known is a subpopulation of AMPA receptors that is $\mathrm{Ca}^{2+}$-permeable and has been shown to be synaptically localized on dorsal horn neurons in culture (Gu et al., 1996) and expressed by dorsal horn neurons in situ (Nagy et al., 1994; Engelman et al., 1997). We used kainate-induced cobalt uptake as a functional marker of neurons expressing $\mathrm{Ca}^{2+}$-permeable AMPA receptors and combined this with markers of nociceptive primary afferents in the postnatal rat dorsal horn. We have shown that cobalt- positive neurons are located in lamina I and outer lamina II, a region strongly innervated by nociceptors. These cobaltpositive neurons colocalize with afferents labeled by LD2, and with the most dorsal region of capsaicin-sensitive and IB4- and LA4-positive afferents. In contrast, inner lamina II has a sparser distribution of cobalt-positive neurons. Some lamina I neurons expressing the NK1 receptor, the receptor for substance P, are also cobalt positive. These neurons are likely to be projection neurons in the nociceptive pathway. On the basis of all of these observations, we propose that $\mathrm{Ca}^{2+}$-permeable AMPA receptors are localized to mediate transmission of nociceptive information.

Key words: dorsal horn; calcium-permeable AMPA receptors; glutamate; cobalt; spinal cord; NK1 receptor; dorsal root ganglia; nociception
Nociceptive transmission is often strengthened under pathological conditions, resulting in hyperalgesia, allodynia, or chronic pain. In the spinal cord dorsal horn, glutamate is a fast excitatory transmitter that mediates much of the nociceptive signaling and may be responsible for induction of central sensitization associated with altered nociception. Glutamate is released from both primary afferents and excitatory interneurons onto postsynaptic NMDA and non-NMDA glutamate receptor subtypes (Yoshimura and Jessell, 1990). $\mathrm{Ca}^{2+}$ entry through NMDA receptors is known to activate $\mathrm{Ca}^{2+}$-sensitive signaling cascades and potentiate synaptic transmission (for review, see McBain and Mayer, 1994). Some AMPA and kainate receptors also have significant $\mathrm{Ca}^{2+}$ permeability (for review, see Hollmann and Heinemann, 1994; Jonas and Burnashev, 1995) and may activate pathways leading to synaptic strengthening (Gu et al., 1996; Jia et al., 1996; Mahanty and Sah, 1998).

AMPA receptors are multimeric assemblies of four cloned subunits: GluR1-4 (or GluRA-D). The GluR2 (GluRB) subunit determines the $\mathrm{Ca}^{2+}$ permeability of these ligand-gated ion channels. GluR2 transcripts undergo RNA editing, producing a one-

\footnotetext{
Received Sept. 18, 1998; revised Dec. 3, 1998; accepted Jan. 6, 1999.

This work was supported by the American Paralysis Association and National Institutes of Health. We thank Susan Morton for help with monoclonal antibody harvesting, Jane Dodd for providing antibodies and valuable advice on the immunocytochemistry, C. Justin Lee for help in getting the project started, and Cristóvão Albuquerque, C. Justin Lee, and Charalampos Labrakakis for comments on this manuscript.

Correspondence should be addressed to Holly S. Engelman, Department of Physiology and Cellular Biophysics, Columbia University, 630 W. 168th Street, BB1106, New York, NY 10032.
}

Copyright (C) 1999 Society for Neuroscience $\quad 0270-6474 / 99 / 192081-09 \$ 05.00 / 0$ amino acid change in the channel pore that decreases $\mathrm{Ca}^{2+}$ permeability (Burnashev et al., 1992). Recent studies suggest that one edited GluR2 subunit is sufficient to cause low receptor $\mathrm{Ca}^{2+}$ permeability (Washburn et al., 1997). AMPA receptors lacking GluR2 have $\mathrm{Ca}^{2+}$ permeability ratios up to $P_{\mathrm{Ca}} / P_{\mathrm{Na}}=3$ (Hollmann et al., 1991; Hume et al., 1991; Burnashev et al., 1992; Geiger et al., 1995; Jia et al., 1996).

Calcium-permeable non-NMDA receptors have been demonstrated in dorsal horn neurons in vitro by $\mathrm{Ca}^{2+}$ detection using indicator dyes (Reichling and MacDermott, 1993), ion permeability studies (Goldstein et al., 1995), and pharmacology (Gu et al., 1996). These receptors participate in synaptic transmission in vitro (Gu et al., 1996) and may also be present at synaptic sites in vivo. In dorsal horn $\mathrm{C} 1$ glomeruli, a higher percentage of postsynaptic AMPA receptor clusters is immunopositive for GluR1 than for GluR2 (Popratiloff et al., 1996), suggesting that AMPA receptors lacking GluR2 may participate in synaptic transmission between dorsal root ganglia (DRG) and dorsal horn neurons.

To determine the role of $\mathrm{Ca}^{2+}$-permeable non-NMDA receptors in nociceptive sensory transmission, we functionally identified dorsal horn neurons expressing these receptors using the kainate-induced cobalt-loading technique (Pruss et al., 1991). Previously, Nagy et al. (1994) used this method to demonstrate cobalt loading of cells in all laminae of the hemisected spinal cord preparation, including the superficial dorsal horn. We extended these studies in spinal cord slices, using more specific antagonists of non-NMDA receptors to verify that this technique is specific for $\mathrm{Ca}^{2+}$-permeable AMPA receptors. We localized cobaltpositive neurons with respect to AMPA receptor subunits and markers of nociceptive afferents. We found that $\mathrm{Ca}^{2+}$-permeable 
AMPA receptors are expressed by subsets of superficial dorsal horn neurons, including putative projection neurons. Other studies indicate that these receptors are also expressed by inhibitory dorsal horn neurons in culture (Albuquerque and MacDermott, 1998) and in situ (Spike et al., 1998). These observations indicate a complex role for $\mathrm{Ca}^{2+}$-permeable AMPA receptors in the circuitry of the spinal cord dorsal horn.

A preliminary account of this work has been published previously in abstract form (Engelman et al., 1997).

\section{MATERIALS AND METHODS}

Preparation of slices. Postnatal day 6-14 (P6-14) rat pups were anesthetized with isoflurane and decapitated, and their spinal cords were dissected out in ice-cold Krebs' buffer containing (in mM): $125 \mathrm{NaCl}, 2.5$ $\mathrm{KCl}, 26 \mathrm{NaHCO}_{3}, 1.25 \mathrm{NaH}_{2} \mathrm{PO}_{4}, 25$ glucose, $2 \mathrm{CaCl}_{2}, 1 \mathrm{MgCl}_{2}$ bubbled with $95 \% \mathrm{O}_{2} / 5 \% \mathrm{CO}_{2}$. The lumbar spinal cord of each pup was glued by its ventral side with cyanoacrylate to a $2 \%$ agar block, and 400 $\mu \mathrm{m}$ slices were prepared using the Vibratome Series 1000 . Slices were left to recover in bubbled Krebs at $37^{\circ} \mathrm{C}$ for $1 \mathrm{hr}$. In a few cases, slices were made with DRG attached (as in the case of capsaicin-induced cobalt loading).

Agonist-induced cobalt loading. To minimize cell depolarization over long periods and possible $\mathrm{Ca}^{2+}$-associated damage to cells, we followed the example of Pruss et al. (1991), who used a low-sodium and low-Ca ${ }^{2+}$ bath during agonist application. We used bicarbonate buffer instead of HEPES buffer in our bath solution to better approximate in vivo conditions for these neurons. Although cobalt can form an insoluble salt with bicarbonate, we empirically found that at the concentrations used we did not see a precipitate.

Slices were transferred into a prestimulation solution of $95 \% \mathrm{O}_{2} /$ $5 \% \mathrm{CO}_{2}$-bubbled low-sodium, low-calcium Krebs' solution containing (in mu): $50 \mathrm{NaCl}, 2.5 \mathrm{KCl}, 26 \mathrm{NaHCO}_{3}, 1.25 \mathrm{NaH}_{2} \mathrm{PO}_{4}, 25$ glucose, 0.5 $\mathrm{CaCl}_{2}, 2 \mathrm{MgCl}_{2}$, with either 135 sucrose or $80 \mathrm{NMDG}$ to adjust for the low sodium, at room temperature for $15 \mathrm{~min}$. This solution and the stimulation solution always contained $0.5 \mu \mathrm{M}$ TTX and either a nonNMDA receptor antagonist or an equal volume of its vehicle (DMSO or water). Antagonists were used at the following concentrations: CNQX, $50 \mu \mathrm{M}$; GYKI 53655, $100 \mu \mathrm{M}$; APV, $100 \mu \mathrm{M}$. For joro spider toxin (JsTx) treatment, 5 or $10 \mu \mathrm{M}$ JsTx was applied with $250 \mu \mathrm{M}$ kainate in the prestimulation solution, with control slices also receiving the same concentration of kainate.

For stimulation of loading, the above solutions were replaced with identical solutions containing $250 \mu \mathrm{M}$ kainate and $1.5 \mathrm{~mm} \mathrm{CoCl}_{2}$, or kainate and cobalt were added to the above solutions to these final concentrations. For capsaicin-induced cobalt loading, $10 \mu \mathrm{M}$ capsaicin and $1.5 \mathrm{~mm} \mathrm{CoCl}_{2}$ were added. The slices were incubated in these solutions at room temperature for $20 \mathrm{~min}$ and were then treated with normal Krebs' solution (without divalent cations) containing $5 \mathrm{~mm}$ EDTA for $10 \mathrm{~min}$. They were then rinsed in normal Krebs' solution and incubated in a $0.12 \%$ solution of $\left(\mathrm{NH}_{4}\right)_{2} \mathrm{~S}$ in normal Krebs' solution for 5-6 min. They were rinsed again in normal Krebs' solution and fixed in cold $4 \%$ paraformaldehyde in $0.1 \mathrm{M}$ phosphate buffer $(\mathrm{PB})$ overnight at $4^{\circ} \mathrm{C}$.

The following day, slices were rinsed in $0.1 \mathrm{M}$ phosphate buffer and then switched to a solution of $30 \%$ sucrose in $0.1 \mathrm{~m}$ phosphate buffer until they equilibrated. The slices were mounted with OCT for cryostat sectioning. Sections of 15-30 $\mu \mathrm{m}$ were prepared and mounted on Superfrost Plus slides. These sections were processed to enhance the CoS reaction product by silver intensification (Davis, 1982), or first processed for immunocytochemistry.

Silver intensification. The sections were incubated in a $2 \%$ solution of sodium tungstate for $10 \mathrm{~min}$, followed by $15-20 \mathrm{~min}$ in developer consisting of one part $5 \%$ sodium tungstate, eight parts $\mathrm{AgNO}_{3}$ solution (355 $\mathrm{ml}$ of distilled water, $15 \mathrm{ml}$ of $1 \%$ Triton X-100, $1.5 \mathrm{gm}$ of sodium acetate ${ }^{3} \mathrm{H}_{2} \mathrm{O}, 30 \mathrm{ml}$ of glacial acetic acid, and $0.5 \mathrm{gm}$ of silver nitrate), and one part $0.25 \%$ ascorbic acid. The sections were rinsed again in $2 \%$ sodium tungstate and then mounted in either $50 \%$ glycerol $/ 50 \%$ PBS, Gel/Mount, $2.5 \%$ 1,4-diazabicyclo[2,2,2]octane (DABCO) in $90 \%$ glycerol/10\% PBS for slides containing Cy3-labeled fluorescent antibodies, or ProLong Antifade for slides containing Alexa 488-conjugated secondary antibodies.

Preparation of fixed spinal cords. Perfusion of rat pups for studying the in situ distribution of antigens was performed under isoflurane anesthesia. Each animal was perfused by injection of $20 \mathrm{ml} 0.1 \mathrm{M} \mathrm{PB}$ followed by
$20 \mathrm{ml}$ of $4 \%$ paraformaldehyde fixative into the heart. The spinal cord and DRGs were dissected out and post-fixed for $2 \mathrm{hr}$ to overnight in $4 \%$ paraformaldehyde. After rinsing in $0.1 \mathrm{M} \mathrm{PB}$, the spinal cord and DRGs were transferred to $30 \%$ sucrose in $0.1 \mathrm{M}$ phosphate buffer until the tissue equilibrated. The lumbar enlargement was isolated and mounted in OCT for production of transverse sections. Fresh frozen DRGs were prepared by mounting unfixed DRGs directly in OCT; $15-30 \mu \mathrm{m}$ sections were prepared as described for slices.

Immunocytochemistry. Primary antibodies were diluted in PBS with $0.1 \%$ Triton X-100 and 1\% normal goat serum (PBS-TG). Monoclonal mouse anti-GluR2 or polyclonal rabbit anti-GluR1 were used at concentrations of $1 \mu \mathrm{g} / \mathrm{ml}$. Polyclonal anti-NK1 antisera were diluted 1:5000. LA4 ascites fluid was diluted 1:100, and LD2 supernatant was diluted 1:1. For staining with IgG antibodies, sections were first incubated in a blocking solution of $10 \%$ normal goat serum in PBS with $0.1 \%$ Triton $\mathrm{X}-100$. Primary antibody solution was applied overnight at $4^{\circ} \mathrm{C}$ for $\operatorname{IgM}$ antibodies or for $2 \mathrm{hr}$ at room temperature. Parallel sections were routinely incubated in the same solutions lacking primary antibody for a negative control. Sections were rinsed and incubated in Cy3-conjugated secondary antibodies (goat anti-mouse IgG, goat anti-rabbit IgG, or goat anti-mouse $\mathrm{IgM}$ ) diluted 1:500 in PBS-TG. Sometimes mounting of sections was followed by image acquisition, unmounting in PBS, and subsequent silver intensification as above. DRG fresh-frozen sections from P13 pups were similarly stained for LA4 and LD2, but without Triton X-100 in dilution buffers.

For staining with IB4, sections were incubated with IB4-biotin at a concentration of $5-10 \mu \mathrm{g} / \mathrm{ml}$ in PBS-TG for $2 \mathrm{hr}$ at room temperature. Parallel sections were routinely incubated in the same solutions lacking IB4 for a negative control. Sections were then rinsed and incubated with streptavidin-Alexa 488 at $10 \mu \mathrm{g} / \mathrm{ml}$ for $45 \mathrm{~min}$.

Monoclonal mouse anti-GluR2 and polyclonal rabbit anti-GluR1 were purchased from Chemicon (Temecula, CA). Rabbit anti-NK1 antisera were a gift from S. R. Vigna (Duke University). LA4 and LD2 were a gift from J. Dodd (Columbia University). Cy3-conjugated secondary antibodies were from Jackson ImmunoResearch (West Grove, PA). Alexa 488-conjugated secondary antibodies, streptavidin-Alexa 488, and ProLong Antifade were from Molecular Probes (Eugene, OR). Gel/Mount and Superfrost Plus slides were from Fisher Scientific (Pittsburgh, PA). IB4-biotin, DABCO, capsaicin, TTX, and all salts for solutions were from Sigma (St. Louis, MO). Kainate was from RBI (Natick, MA), CNQX and APV were from Tocris (Ballwin, MO), and JsTx-3 was from RBI and Calbiochem (La Jolla, CA). GYKI 53655 was a generous gift from Eli Lilly (Indianapolis, IN).

Analysis of distribution of cobalt-positive neurons and IB4-positive fibers. Digital images of cobalt staining and IB4 staining of double-labeled sections were acquired with a Dage RC300 CCD camera. For each of 16 IB4 fluorescence images, a $120 \times 100 \mu \mathrm{m}$ box was placed on the lateral edge of the IB4 staining. The box extended through laminae I and II and part of lamina III. Pixel values from 0-255 gray levels were averaged vertically to produce one intensity value for each column of pixels within the box, resulting in average intensity values over the horizontal extent of the box of the IB4 data. The box from the IB4 image was placed at the same coordinates on the corresponding transmitted light image of the same section, and average gray values for each column were again calculated for the cobalt staining. The data from the two sets of average intensities were normalized for maximum and minimum, the IB4 data were inverted, and both sets of data were plotted as a function of distance from the lateral edge of the IB4 staining (see Fig. 5). Normalized values were used when averaging data from multiple sections.

Analysis of NK1 and cobalt colocalization. Sections of kainate-induced cobalt-labeled slices were stained for NK1 receptor-like immunoreactivity (NK1-LI). Silver intensification was used to detect kainate-induced cobalt signaling in NK1-LI-positive cells. Cells that retained their NK1-LI after silver intensification were checked for the presence of cobalt. A cell was considered positive for NK1-LI if the edge of its soma was rimmed with NK1 staining. Many of these cells also had visible NK1-LI processes.

\section{RESULTS}

\section{Patterns of kainate-induced cobalt loading}

Application of $250 \mu \mathrm{M}$ kainate and $1.5 \mathrm{~mm}$ cobalt to spinal cord slices in the presence of $0.5 \mu \mathrm{M}$ TTX caused staining of presumptive neuronal cell bodies and some processes from the most dorsal to the most ventral laminae. In the dorsal horn, the staining 


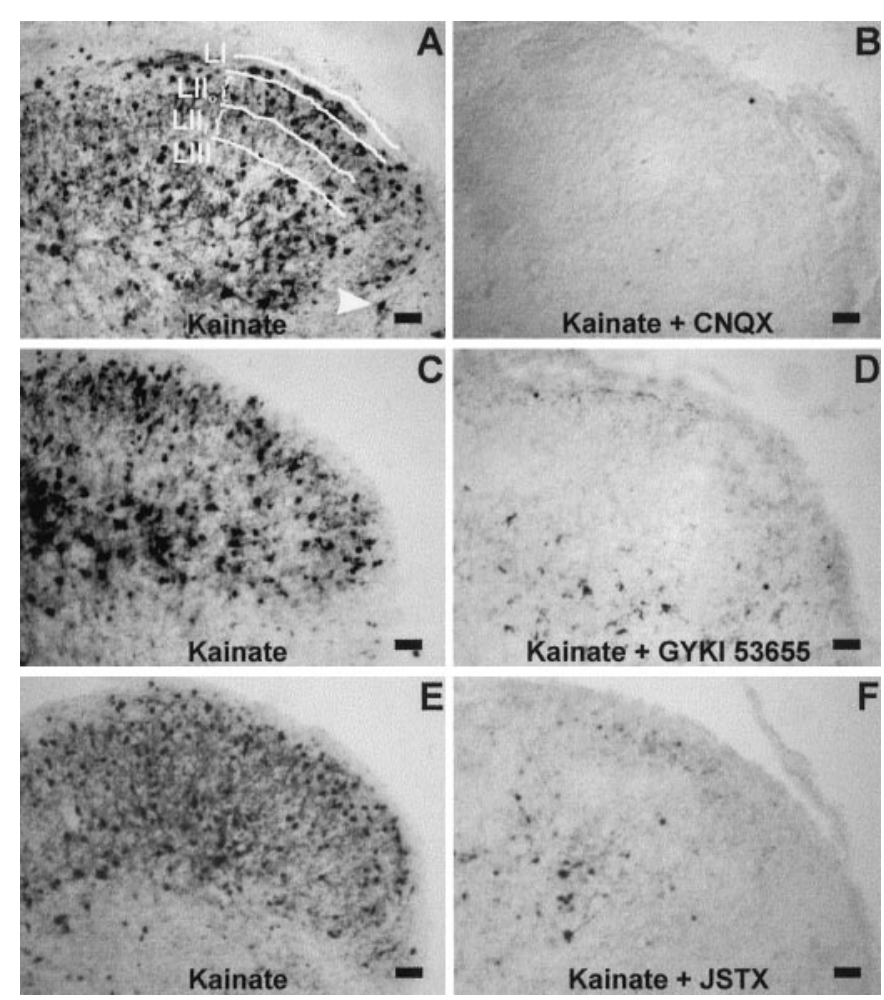

Figure 1. Kainate-induced cobalt loading in the dorsal horn: antagonism by CNQX, GYKI 53655, and JsTx. $A, B$, Kainate-induced cobalt loading in a $\mathrm{P} 9$ rat spinal cord slice is shown. Slices were treated with $250 \mu \mathrm{M}$ kainate $(A)$ or $250 \mu \mathrm{M}$ kainate plus $50 \mu \mathrm{M} \operatorname{CNQX}(B)$. White lines in $A$ delineate our approximations of dorsal horn laminae. A subpopulation of neurons in the most dorsal laminae, lamina $\mathrm{I}(L I)$ and outer lamina II $\left(L I I_{o}\right)$, show strong evidence of kainate-induced cobalt loading (black cells), with fewer cobalt-positive cells in inner lamina II $\left(L I I_{i}\right)$, and more cobalt-positive cells in the more ventral laminae (e.g., lamina III). A white arrowhead points to a cobalt-positive cell in the lateral spinal nucleus. CNQX blocked kainate-induced cobalt loading of cells throughout the spinal cord. $C, D$, Kainate-induced cobalt loading in a P10 rat spinal cord slice is shown. Slices were treated with $250 \mu \mathrm{M}$ kainate $(C)$ or $250 \mu \mathrm{M}$ kainate plus $100 \mu \mathrm{M}$ GYKI $53655(D) . E$, $F$, Kainate-induced cobalt loading in a P10 rat spinal cord slice is shown. Slices were treated with 250 $\mu \mathrm{M}$ kainate $(E)$ or $250 \mu \mathrm{M}$ kainate plus $5 \mu \mathrm{M}$ JsTx $(F)$. A few sparse cells are labeled in the presence of GYKI $53655(D)$ or JsTx $(F)$. Scale bars, $40 \mu \mathrm{m}$.

seemed to occur along laminar boundaries. We reliably saw staining in lamina I and in the more dorsal aspect of lamina II, but saw sparser staining in what appeared to be the more ventral portion of lamina II. In laminae III and IV, we again saw a denser staining (Fig. $1 A, C, E$ ). We occasionally observed staining in the lateral spinal nucleus (Fig. 1A). The gap seen in presumptive inner lamina II was not always present, although in some cases this may have been because of the angle of the section. In addition, the area around the central canal and ventral motorneurons varied in the number of cobalt-positive neurons.

\section{Antagonism of kainate-induced cobalt loading}

To ensure that kainate-induced cobalt loading in each experiment resulted from activation of non-NMDA receptors rather than poor slice health or kainate acting on another target, we routinely included control slices incubated with kainate plus $50 \mu \mathrm{M} \mathrm{CNQX}$, a competitive antagonist of non-NMDA receptors. All cobalt loading in the dorsal horn was blocked in the presence of this antagonist (Fig. 1B), implicating ligand-gated non-NMDA receptors in the pathway to cobalt entry ( 84 slices treated with kainate alone, 68 with kainate and CNQX; 22 animals). The NMDA receptor antagonist APV $(100 \mu \mathrm{M})$ did not block kainate-induced cobalt loading in slices (data not shown). To test whether depolarization alone leads to cobalt loading, slices were treated with bath solution containing $50 \mathrm{~mm} \mathrm{KCl}$. As demonstrated previously in cultured cerebellar neurons (Pruss et al., 1991) and in the hemisected spinal cord preparation (Nagy et al., 1994), this solution did not elicit cobalt entry, indicating that kainate was not acting simply by depolarization (data not shown). We also performed a more depolarizing control with $125 \mathrm{~mm} \mathrm{KCl}$ (data not shown). This solution elicited staining in the dorsal horn in a pattern different from that of kainate and cobalt, with some cell bodies and some punctate staining present. This pattern was not blocked by $50 \mu \mathrm{M}$ GYKI 53655 or by $50 \mu \mathrm{M}$ CNQX and may be caused by release of an unknown transmitter with a cobaltpermeable receptor.

Kainate is an agonist at both AMPA- and kainate-preferring subtypes of non-NMDA receptors. There is evidence for expression of both of these receptor subtypes within the spinal cord, as well as in primary afferents innervating the dorsal horn (Huettner, 1990; Tolle et al., 1993; Petralia et al., 1994; Tachibana et al., 1994). To test whether kainate-induced cobalt loading is caused by activation of AMPA or kainate receptors, we used GYKI 53655, a selective noncompetitive antagonist of AMPA receptors. We used $100 \mu \mathrm{M}$ GYKI 53655, a concentration that should fully block AMPA receptors but only $20 \%$ of kainate receptor current (Wilding and Huettner, 1995). GYKI 53655 blocked kainateinduced cobalt loading in dorsal horn neurons (Fig. 1C,D) (nine slices each condition; three animals). This indicates that activation of AMPA receptors, but not kainate receptors, is necessary for kainate-induced cobalt loading. At a concentration of $50 \mu \mathrm{M}$, GYKI 53655 also abolished kainate-induced cobalt loading (data not shown) (four slices; one animal).

To discern whether the cobalt loading required current flow directly through the $\mathrm{Ca}^{2+}$-permeable subtype of AMPA receptor or was secondary to activation of $\mathrm{Ca}^{2+}$-impermeable receptors, we used JsTx, an antagonist of $\mathrm{Ca}^{2+}$-permeable non-NMDA receptors. This toxin has been shown to block AMPA and kainate receptors lacking subunits edited at the $Q / R$ site in the channel pore (Blaschke et al., 1993). In contrast, receptors with subunits containing an arginine at this position are not $\mathrm{Ca}^{2+}$-permeable and are not blocked by this antagonist. This toxin is both usedependent and voltage-dependent (Blaschke et al., 1993; Iino et al., 1996). To maximize the use-dependent block with JsTx, we applied it with kainate before addition of cobalt to the slice (see Materials and Methods). Only a few cells in dorsal horns treated with kainate and 5-10 $\mu \mathrm{M}$ JsTx were stained relative to control slices treated with kainate alone (Fig. 1E,F) (eight slices each condition; three animals). JsTx blocked kainate-induced cobalt loading of neurons most effectively in the superficial dorsal horn, but interestingly, often did not block staining of more ventral cells in the spinal cord (data not shown). The reduction of staining in the dorsal horn in the presence of JsTx suggests that cobalt entry is dependent on $\mathrm{Ca}^{2+}$-permeable AMPA receptors. Taken together, these antagonist data suggest that in postnatal spinal cord dorsal horn, $\mathrm{Ca}^{2+}$-permeable AMPA receptors are responsible for kainate-induced cobalt uptake.

\section{GluR1 and GluR2 subunit expression and kainate- induced cobalt loading}

In a given cell, the ratio of GluR2 expression to that of other AMPA receptor subunits has been shown to correlate inversely 

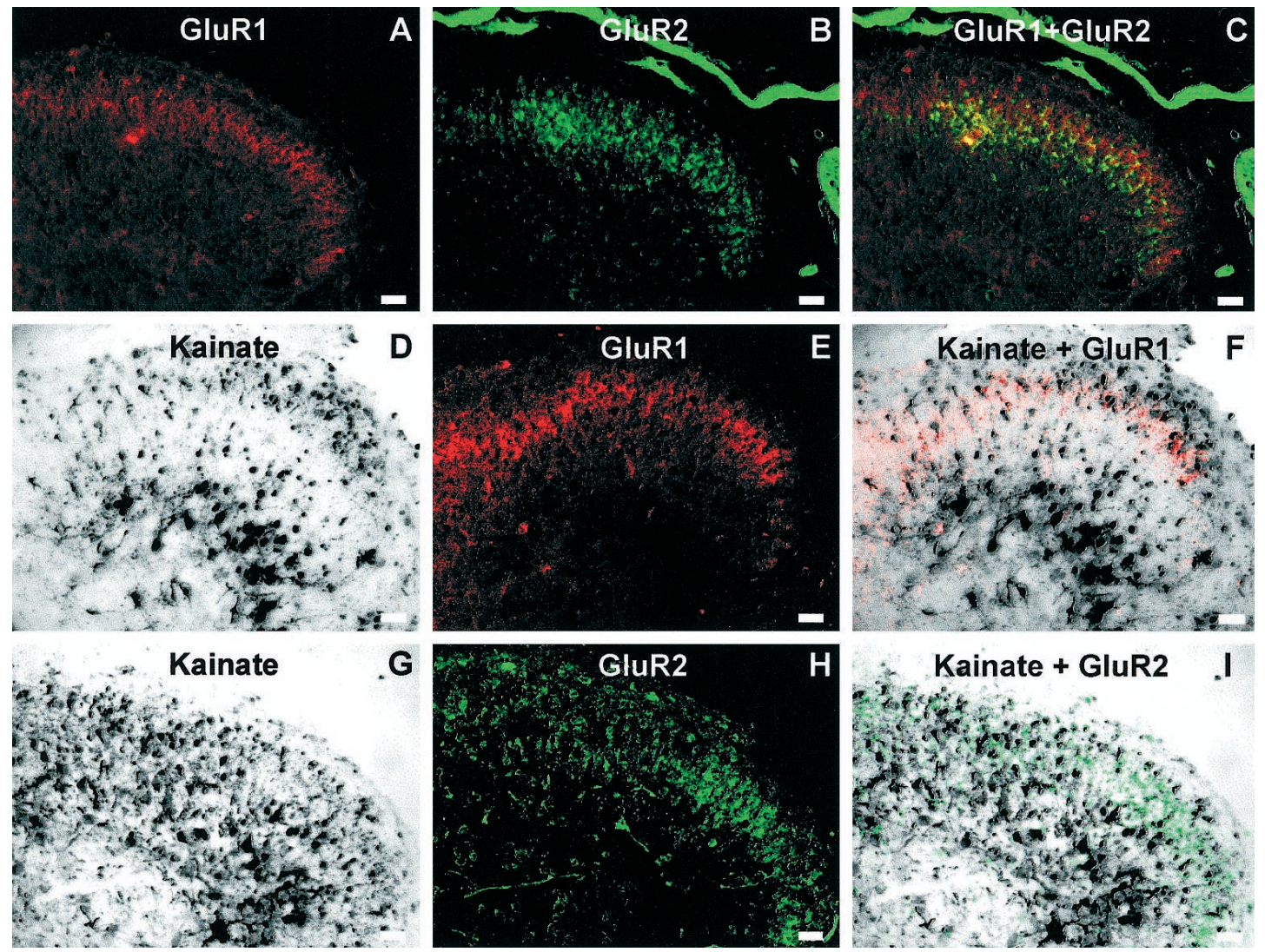

Figure 2. GluR1 and GluR2 distribution in spinal cord dorsal horn: double labeling with kainate-induced cobalt uptake. $A-C$, GluR1 staining (red, $A$ ) and GluR2 staining (green, $B$ ) are shown in the same transverse section from a P10 rat spinal cord. Images of GluR1 and GluR2 staining are superimposed in $C$. GluR1 is present in many cells throughout the spinal cord and forms a laminar pattern in the superficial dorsal horn, strongest in outer lamina II. GluR2 is also found in lamina II and is strongest slightly ventral to the area of highest GluR1 expression. $D-F$, Kainate-induced cobalt loading $(D)$ and GluR1 staining $(E)$ were performed sequentially on the same sections using tissue from a P8 rat spinal cord slice (see Materials and Methods). The GluR1 $(E)$ and kainate $(D)$ patterns have been superimposed in $F$ to reveal that the area of high GluR1 expression corresponds to that with kainate-induced cobalt loading. $G-I$, Kainate-induced cobalt loading $(G)$ and GluR2 staining $(H)$ were performed sequentially using tissue from a P10 rat spinal cord slice (see Materials and Methods). The GluR2 $(H)$ and kainate-induced cobalt $(G)$ patterns have been superimposed in $I$ to reveal that the area of high GluR2 expression corresponds to that of the gap in kainate-induced cobalt loading in the superficial dorsal horn. Scale bars, $40 \mu \mathrm{m}$.

with the percentage of assembled AMPA receptors that are $\mathrm{Ca}^{2+}$-permeable and therefore cobalt-permeable (Geiger et al., 1995). We predicted that inner lamina II would have a higher ratio of GluR2 to other subunits than more superficial dorsal horn regions because it has a smaller number of cells with kainateinduced cobalt uptake. We focused on subunits GluR1 and GluR2 because these are known to be present in the substantia gelatinosa within the second postnatal week, both by in situ hybridization and by immunostaining (Jakowec et al., 1995a,b). We first determined the distribution of GluR1 and GluR2 in transverse spinal cord sections and then performed double labeling of slices using kainate-induced cobalt loading and immunocytochemistry to GluR1 and GluR2 (Fig. 2). We performed simultaneous immunostaining for GluR1 and GluR2 in fixed sections of spinal cord (Fig. $2 A-C$ ) (two animals). GluR2 staining is strongest in the superficial dorsal horn, where it appears to be most prominent in lamina II (Fig. 2B). GluR1 is concentrated in the more dorsal area of this lamina (Fig. $2 A, C$ ), whereas GluR2 staining is stronger in inner lamina II (Fig. $2 C$ ). This pattern is similar to that seen by Popratiloff et al. (1996) in the adult rat using antibodies to GluR1 and GluR2/3 subunits. It is consistent with our earlier observation that cobalt-permeable AMPA receptors are present on neurons in outer lamina II and lamina I, and sparser in inner lamina II.
We immunostained sections of kainate-induced cobalt-loaded slices to colocalize GluR1 and GluR2 with cobalt-positive neurons. In the example shown in Figure $2 D-F$, cobalt-positive cells were found laterally in laminae I and III and with lighter cobaltpositive cell density medially. GluR1 staining was again localized to a band in the superficial dorsal horn, and it colocalized with the dorsal clusters of cobalt-positive neurons in the lateral region (Fig. $2 F$ ) (three slices; one animal). In a different preparation, the area of strongest GluR2 staining (Fig. 2G) (17 slices; four animals) was located laterally between the regions of cobalt-positive cells in outer lamina II and those in lamina III (Fig. 2H,I). GluR1 and cobalt loading are both strongly expressed in the same outer region of lamina II, suggesting that this region of low GluR2 and high GluR1 expression has cells with $\mathrm{Ca}^{2+}$-permeable AMPA receptors.

\section{Calcium-permeable AMPA receptors and nociceptive afferents}

To better localize neurons expressing $\mathrm{Ca}^{2+}$-permeable AMPA receptors in the developing dorsal horn, we compared their distribution with that of nociceptive afferent fibers. Capsaicin acts selectively on nociceptor primary afferents (for review, see Fitzgerald, 1983), and the capsaicin receptor is directly permeable to cobalt (Winter, 1987; Wood et al., 1988). As reported 

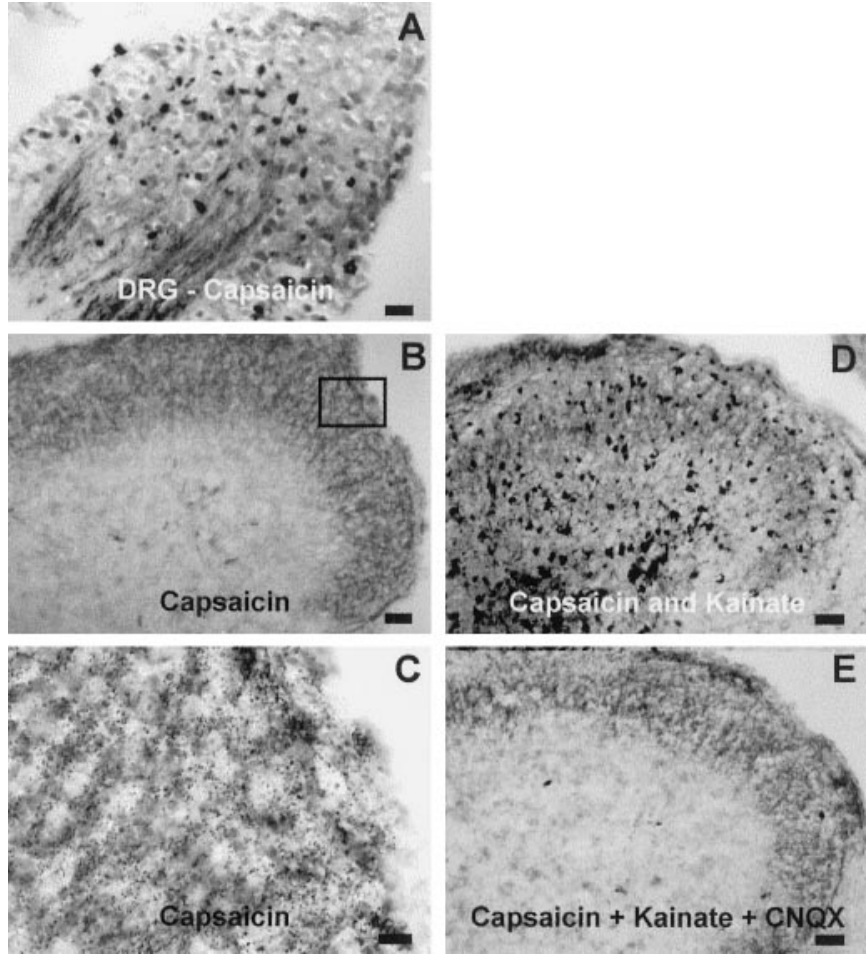

Figure 3. Capsaicin-induced cobalt entry serves as a marker for nociceptive DRG neurons and their nerve terminals in the dorsal horn. Kainate-induced cobalt-loaded cells are found in the region of capsaicinresponsive nociceptive afferents. $A$, Capsaicin $(10 \mu \mathrm{M})$ caused cobalt loading of a subpopulation of small neurons in the DRG $(A)$ of a P6 rat. $B, C$, Capsaicin-induced cobalt loading also labeled the central processes of DRG neurons $(B, C)$ in slices from a $\mathrm{P} 9$ rat. The central terminals of the capsaicin-sensitive primary afferents are seen to innervate laminae I and II of the spinal cord. The boxed area in $B$ is magnified in $C$, where presumptive afferent axons and terminals are seen in a punctate pattern. $D, E$, Kainate- and capsaicin-induced cobalt loading in the same P6 slice. Kainate-induced cobalt-positive neurons (black spots in the area of the superficial dorsal horn) are present in the region of capsaicin-sensitive nociceptive fibers ( fine black speckling) $(D)$. In another section from the same spinal cord, the kainate-induced cobalt loading was blocked with 50 $\mu \mathrm{M} C \mathrm{CNQX}$, leaving the capsaicin-induced staining pattern more apparent (E). Scale bars: $A, B, D, E, 40 \mu \mathrm{m} ; C, 10 \mu \mathrm{m}$.

previously (Nagy et al., 1993), application of capsaicin to the DRG in the presence of cobalt allows detection of capsaicinsensitive neurons. In our experiments, capsaicin induced cobalt loading in the soma and processes of small-diameter sensory neurons in the DRG (Fig. $3 A$ ) (one slice; one animal).

Application of capsaicin and cobalt to spinal cord slices resulted in a punctate pattern of staining in laminae I and II of the dorsal horn (Fig. 3B) (18 slices; five animals). Higher magnification revealed that the puncta seemed to surround cell bodies, as would be expected of primary afferent fibers (Fig. 3C). Expression of capsaicin receptors on the central terminals of primary afferents has been demonstrated previously by binding of the potent capsaicin receptor agonist resiniferotoxin in the dorsal horn (Szallasi et al., 1995). No staining of dorsal horn neurons was seen with capsaicin-induced cobalt loading, in contrast to the pattern seen with kainate-induced cobalt loading. Application of both kainate and capsaicin with cobalt resulted in labeling of both dorsal horn cell bodies and afferents (Fig. 3D). Labeled superficial dorsal horn neurons were concentrated in the outermost region of capsaicin staining. Simultaneous application of kainate,
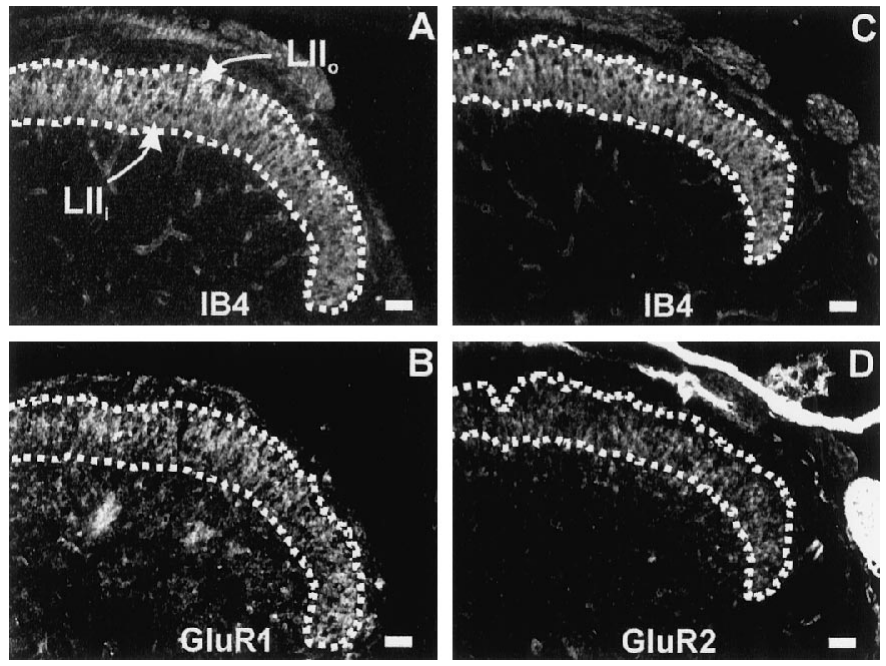

Figure 4. The primary afferent marker, IB4, overlaps with GluR1- and GluR2-positive areas in the superficial dorsal horn. $A, B$, Staining with the lectin IB4 $(A)$ and antibodies to GluR1 $(B)$ are shown from the same transverse section from fixed P10 rat spinal cord. The area of IB4-positive terminals has been outlined in white dashes to compare the distribution of IB4-positive terminals with that of GluR1. Note that IB4 spans the outer and inner regions of lamina II in this preparation. GluR1 staining is seen in the outermost region of IB4 staining. $C, D$, Staining with the lectin IB4 $(C)$ and antibodies to GluR2 $(D)$ are shown in this transverse section from fixed P10 rat spinal cord. The area of IB4-positive terminals has been outlined in white dashes to compare the distribution of IB4-positive terminals with that of GluR2. GluR2 staining is seen in the innermost region of IB4 staining. Scale bars, $40 \mu \mathrm{m}$.

capsaicin, and CNQX together with cobalt blocked only the kainate-induced dorsal horn cell body labeling, leaving the labeling of afferent fibers unaffected (Fig. 3E). These results demonstrate that neurons in the areas of the superficial dorsal horn receiving nociceptive afferent input contain $\mathrm{Ca}^{2+}$-permeable AMPA receptors.

Nociceptors can be classified into subpopulations according to expression of peptides, enzymes, and surface markers. We examined the colocalization of kainate-induced cobalt-positive dorsal horn neurons with three surface markers of lamina II afferent fibers: IB4, LD2, and LA4. The lectin IB4 labels small-diameter afferents that downregulate TrkA expression during the first 3 postnatal weeks and become sensitive to the trophic factor GDNF (Molliver and Snider, 1997; Molliver et al., 1997). They project to inner lamina II in adult rat spinal cord (Molliver et al., 1995). In the second postnatal week, IB4 appears to label afferents projecting throughout lamina II [(Figs. 4A,C (two animals), $5 B]$. We first compared the distribution of IB4 with GluR1 and GluR2 staining. The strongest GluR1 and GluR2 staining overlapped with IB4-positive lamina II. Figure $4 A, B$ shows that GluR1 staining is strongest in the dorsal portion of IB4-positive superficial dorsal horn or outer lamina II. Figure $4 C, D$ shows that GluR2 staining is strongest in the ventral portion of IB4-positive dorsal horn or inner lamina II. These results suggest that the high density of cobalt-positive neurons will be in the dorsal region of IB4-positive fibers, consistent with the results obtained with capsaicin-sensitive fibers.

After kainate-induced cobalt loading, sections were prepared and stained with IB4 (Fig. 5) (eight slices; two animals). We analyzed the relative distribution of IB4-positive fibers and cobalt-positive dorsal horn neurons by plotting the average density of both the cobalt and IB4 signals for a given distance from 

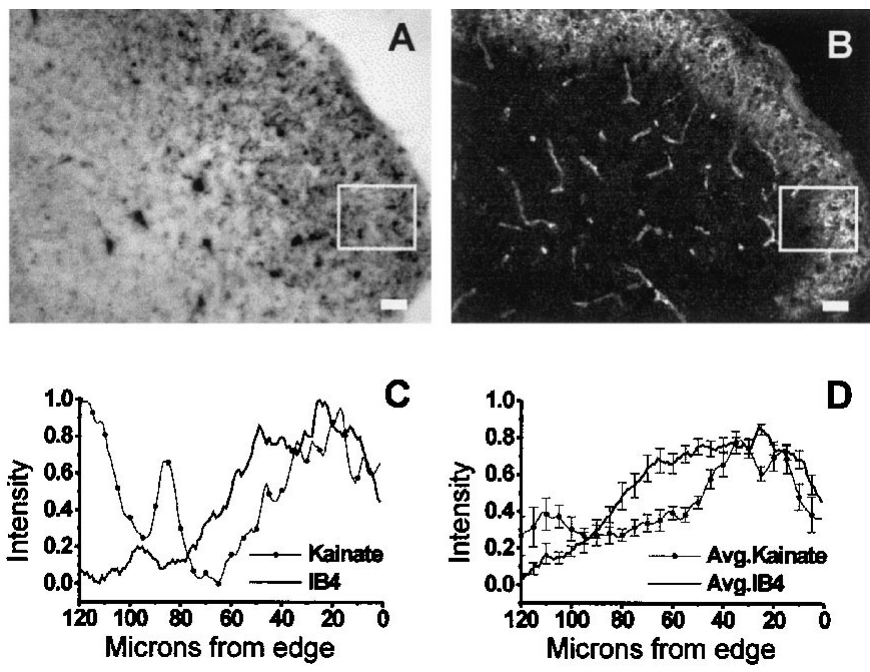

Figure 5. IB4-positive terminals and kainate-induced cobalt loading overlap in the outermost region of IB4 staining. $A, B$, Kainate-induced cobalt loading is seen in this section from a $\mathrm{P} 12$ rat spinal cord slice $(A)$. IB4 labeling of the same section is shown in $B$. A box is placed around a $120 \times 100 \mu \mathrm{m}$ area at the most lateral edge of IB4 staining that was used for the analysis shown in $C$. $C$, Plots of IB4 and cobalt intensity over the $120 \mu \mathrm{m}$ from the lateral edge of IB4 staining for the section displayed in $A$ and $B$. Intensity values are averaged pixel values over $100 \mu \mathrm{m}$ at each distance from the lateral border of IB4 staining. Values have been normalized (see Materials and Methods). D, Plots of IB4 and cobalt intensity over the $120 \mu \mathrm{m}$ from the lateral edge of IB4 staining for average values of 10 sections from multiple slices of the same preparation as $A$ and $B$ (data not shown). Error bars represent the SEM for normalized cobalt and IB4 staining over this region. In both $C$ and $D$, it can be seen that the peak of the kainate-induced cobalt signal in superficial dorsal horn falls in the outermost region of IB4 staining. Scale bars, $40 \mu \mathrm{m}$.

the lateral edge of the IB4 staining (Fig. 5C) (see Materials and Methods). Two patterns of distribution of IB4 and cobalt-positive cells were seen in the lateral dorsal horn. In the majority of sections examined (10/16), cobalt and IB4 colocalized in the dorsal-most region of IB4 staining (Fig. $5 A, B)$. In other sections (6/16), cobalt and IB4 did not have as obvious a relationship in the lateral dorsal horn (data not shown), although the cobalt signal did appear to segregate to the dorsal half of the IB4 region in the medial dorsal horn. To better see the relative staining patterns, we averaged the data for the 10/16 sections that seemed to show a segregation of cobalt-positive cells in the lateral dorsal horn (Fig. 5D). The most cobalt-positive region correlated with the outermost region of IB4 staining, and cobalt loading was decreased in lateral inner lamina II in these 10 sections.

Monoclonal antibodies LD2 and LA4 recognize lactoseries carbohydrate epitopes on the soma and projections of different populations of small diameter DRG neurons (Fig. 6A,D) (Dodd and Jessell, 1985). LD2 marks afferents in the outer portion of lamina II (Fig. 6B), whereas LA4 staining reveals afferents throughout lamina II at this stage of development (Fig. 6E), similar to IB4.

After slices were treated with kainate and cobalt to reveal cells expressing $\mathrm{Ca}^{2+}$-permeable AMPA receptors, sections were prepared and stained with either monoclonal antibody LA4 or LD2. As with IB4, the region of low cobalt density corresponded to the ventral-most area of LA4 staining (Fig. 6F) (29 slices; eight animals). The area labeled by LD2 directly overlapped with that of kainate-positive cells in presumptive outer lamina II (Fig. 6C) (13 slices; three animals). This confirms that most kainate- induced cobalt-positive cells are present in lamina I and in outer lamina II, areas receiving innervation from specifically labeled subpopulations of nociceptive primary afferents.

\section{Correlation with NK1-positive lamina I neurons}

In the adult lumbar spinal cord, long projection neurons account for $\sim 30 \%$ of the neurons in lamina I (Bice and Beal, 1997), and $>70 \%$ of the spinothalamic lamina I neurons express the NK1 receptor, the receptor for substance P (Marshall et al., 1996). We used the NK1 receptor as a marker to examine expression of $\mathrm{Ca}^{2+}$-permeable AMPA receptors by lamina I projection neurons. Of 38 NK1-LI lamina I cells surveyed, 13 were found to be cobalt positive (Fig. $7 A, B$ ). The cobalt stain in these cells was usually not as strong as other cells in the slice and seemed at an intermediate level. This observation correlates with the overlap of NK1-LI and partial cobalt-positive cells seen in cultures of dorsal horn neurons (Albuquerque and MacDermott, 1998; C. Albuquerque, C. J. Lee, A. C. Jackson, and A. B. MacDermott, unpublished observation). An NK1-LI neuron in the lateral spinal nucleus also appeared to be cobalt positive (Fig. $7 C, D$ ). Cells in this nucleus are known to be NK1 positive (Marshall et al., 1996) and project to the same nociceptive brain nuclei as lamina I projection neurons (Swett et al., 1985). These data demonstrate that some of the NK1-LI neurons in lamina I express $\mathrm{Ca}^{2+}$. permeable AMPA receptors.

\section{DISCUSSION}

Our work suggests that kainate-induced cobalt loading in the spinal cord dorsal horn occurs through $\mathrm{Ca}^{2+}$-permeable AMPA receptors on the basis of pharmacological evidence for the involvement of non-NMDA receptors with CNQX, AMPA receptors with GYKI 53655, and $\mathrm{Ca}^{2+}$-permeable non-NMDA receptors with JsTx. We have shown that neurons expressing $\mathrm{Ca}^{2+}$. permeable AMPA receptors are present in the superficial dorsal horn in a laminar distribution. Cells expressing $\mathrm{Ca}^{2+}$-permeable AMPA receptors are present in lamina I and outer lamina II, areas innervated by specific subsets of capsaicin-sensitive afferents. The low number of neurons with $\mathrm{Ca}^{2+}$-permeable AMPA receptors in inner lamina II correlates with the high expression of GluR2 in that region as compared with other AMPA receptor subunits. NK1-positive neurons in lamina I and in the lateral spinal nucleus are positive for $\mathrm{Ca}^{2+}$-permeable AMPA receptors. It is known that $\mathrm{Ca}^{2+}$-permeable AMPA receptors are expressed at synapses and mediate changes in synaptic strength in cultured dorsal horn neurons (Gu et al., 1996). Our data suggest that these receptors may mediate synaptic transmission and modulate synaptic strength in specific laminae of the superficial dorsal horn.

\section{Colocalization with nociceptive afferent markers}

Many dorsal horn neurons expressing $\mathrm{Ca}^{2+}$-permeable AMPA receptors are within the region of the superficial dorsal horn that receives nociceptive input in postnatal animals, as indicated by the pattern of capsaicin-induced cobalt loading of primary afferent terminals (Fig. 3). Previous studies suggest that there are at least three nonoverlapping subpopulations of nociceptive fibers in the rat, all of which show some capsaicin sensitivity (Nagy et al., 1981; Nagy and Hunt, 1982; for review, see Lawson, 1992). These subgroups are defined by the expression of the neuromodulators substance P or somatostatin, or by the enzyme fluoride-resistant acid phosphatase (FRAP). Afferents in each group project to specific areas of the dorsal horn. In adult spinal cord, substance P-positive fibers tend to project to lamina I and outer lamina II 

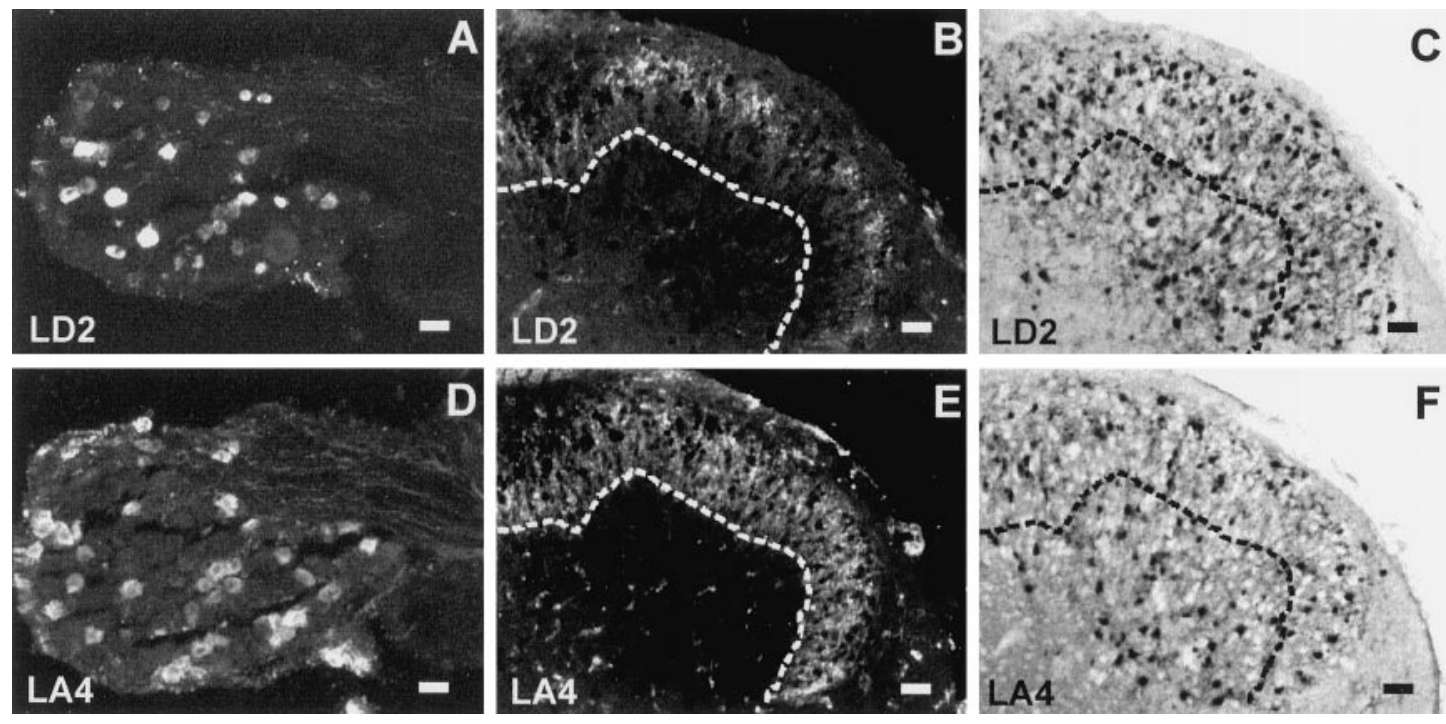

Figure 6. Lactoseries carbohydrate antigens LD2 and LA4 mark subsets of small-diameter DRG neurons and their terminals in the dorsal horn. Kainate-induced cobalt-positive neurons coincide with the area of LD2-positive afferents (presumptive LII $_{\mathrm{o}}$ ), but are sparser in the ventral area of LA4-positive afferents. $A$, The monoclonal antibody LD2 stains a subpopulation of small-diameter DRG neurons. A section from a P13 rat DRG is shown. $B$, LD2-positive primary afferents project primarily to LII $_{\mathrm{o}}$. This section is from a P11 slice that underwent kainate-induced cobalt loading. The border of LA4 staining is predicted using an alternate section from the same slice stained for LA4 (shown in $E$ ) and is marked off with white dashes. Comparison of the staining for LD2 versus LA4 reveals that LD2 distribution is restricted to the most dorsal region of LA4 staining. $C$, The pattern of kainate-induced cobalt loading is shown for the same section as in $B$. The predicted border for the LA4 stain is outlined with black dashes. The area labeled by LD2 directly overlaps with that of cobalt-positive dorsal horn cells in what we presume to be LII $_{\mathrm{o}}$ (compare with $B$ ). $D$, The monoclonal antibody LA4 also stains a subpopulation of small-diameter DRG neurons in P13 rat DRG. E, LA4-positive afferents project throughout LII in this alternate section from the same P11 slice as in $B$ and $C$ (note the wider band of staining for LA4 as compared with LD2 in $B$ ). Dashed lines mark the border of the LA4 staining here and in $F$. F, The pattern of kainate-induced cobalt loading is shown for the same section as in $E$. The inner LA4-positive region of the dorsal horn from another section of the same spinal cord has fewer cobalt-positive dorsal horn neurons than the outermost region. Scale bars, $40 \mu \mathrm{m}$.
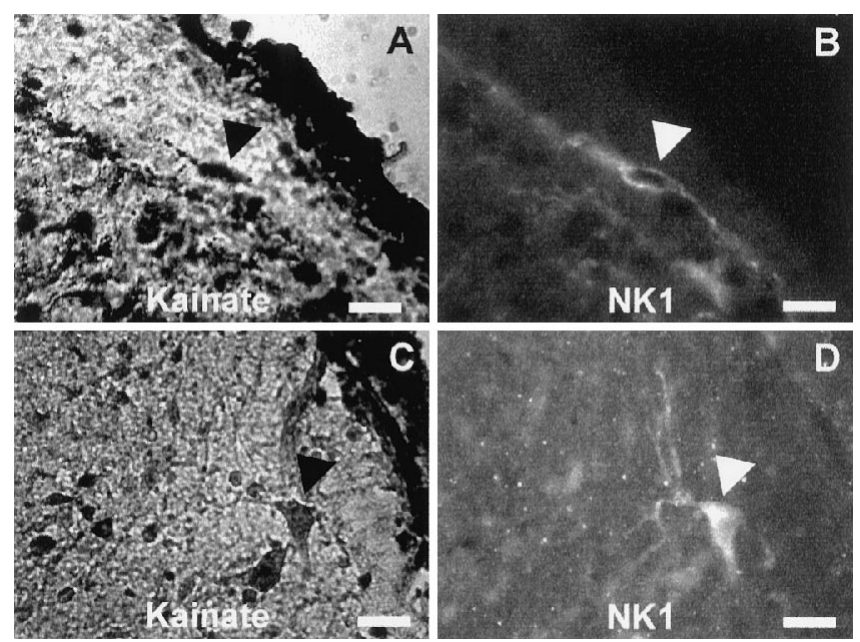

Figure 7. Some NK1-positive neurons also exhibit kainate-induced cobalt loading. $A, B$, Kainate-induced cobalt loading is shown in this $\mathrm{P} 8$ slice $(A)$. The arrowhead marks a lamina I neuron that projects in the transverse plane and is double-labeled for the NK1 receptor $(B) . C, D$, Kainate-induced cobalt loading is shown in a neuron of the lateral spinal nucleus (arrowhead), which is seen below the border of the dorsal horn $(C)$. This neuron is also NK1 positive $(D)$. Scale bars, $20 \mu \mathrm{m}$.

(Todd and Spike, 1993). However, DRG neurons expressing somatostatin and FRAP have a different distribution, as revealed by staining with monoclonal antibodies LD2 and LA4, which do not detect substance P-positive afferents. These antibodies recognize epitopes that appear exclusively on DRG neurons and not on descending or intrinsic spinal cord fibers (Dodd and Jessell,
1985). LD2 marks $100 \%$ of somatostatin-positive neurons and a small percentage $(15 \%)$ of the FRAP-positive population in both intact DRG and cultured neurons. LA4 also labels $100 \%$ of the somatostatin-positive DRG neurons and $>90 \%$ of the FRAPpositive population (Dodd and Jessell, 1985), indicating distribution on a wider population of afferents. Our data suggest that the highest density of neurons expressing $\mathrm{Ca}^{2+}$-permeable AMPA receptors in the superficial dorsal horn are in the regions innervated by nociceptors containing substance P (lamina I and outer lamina II) or somatostatin (outer lamina II).

Patterns of IB4, LD2, and LA4 staining vary postnatally in the developing superficial dorsal horn. Laminar boundaries and primary afferent terminal fields change somewhat over the first 3 postnatal weeks (Coimbra et al., 1986). During the first postnatal week, the width of inner lamina II is smaller than outer lamina II, and FRAP-positive terminals, which are a subset of IB4- and LA4-positive terminals, are found throughout most of inner lamina II. By P15, outer lamina II is becoming smaller than inner lamina II, and the FRAP-positive terminals are increasingly restricted to the dorsal portion of inner lamina II (Coimbra et al., 1986). Our studies were all performed using animals between P6 and P14, a time when the relative widths of inner and outer lamina II and the FRAP-positive (and LA4- and IB4-positive) band of terminals are changing. Our estimation of laminar and sublaminar borders is therefore based on the distribution of our afferent markers at this stage of development.

The presence of $\mathrm{Ca}^{2+}$-permeable AMPA receptor-expressing neurons in lamina I and outer lamina II is consistent with studies of AMPA receptor subunit expression at glomerular synapses between DRG afferents and dorsal horn neurons in adult rats 
(Popratiloff et al., 1996). Electron microscopic studies with GluR1- and GluR2-specific antibodies in adult rat spinal cord indicate that postsynaptic receptor composition varies at different morphological subtypes of glomeruli in the dorsal horn. The central boutons of $\mathrm{C} 1$ glomeruli are capsaicin-sensitive and are thought to arise from unmyelinated $\mathrm{C}$ fibers; these glomeruli are concentrated in outer lamina II and the dorsal aspect of inner lamina II (Ribeiro-da-Silva and Coimbra, 1984; Ribeiro-da-Silva, 1995). Structures postsynaptic to C1 central boutons contain a higher ratio of GluR1 to GluR2 than do receptors postsynaptic to C2 central boutons, which are concentrated in ventral inner lamina II (Popratiloff et al., 1996). This suggests that $\mathrm{Ca}^{2+}$ permeable AMPA receptors are present at synapses between nociceptive DRG afferents and dorsal horn neurons in the adult spinal cord. Our data indicate that this may also be true in the postnatal superficial dorsal horn, although both high-threshold nociceptive afferents and low-threshold non-nociceptive afferents innervate this region during the second postnatal week (Fitzgerald et al., 1994). $\mathrm{Ca}^{2+}$-permeable AMPA receptors at local synapses between dorsal horn neurons have not yet been identified.

\section{Identity of neurons expressing $\mathrm{Ca}^{2+}$-permeable AMPA receptors}

We have shown some coexpression of $\mathrm{Ca}^{2+}$-permeable AMPA receptors and NK1 receptors by lamina I and lateral spinal nucleus neurons. This raises the possibility that NK1-positive projection neurons, the output neurons of the spinal nociceptive circuit, use $\mathrm{Ca}^{2+}$-permeable AMPA receptors to mediate or modulate synaptic transmission, as dorsal horn neurons in culture have been shown to do ( $\mathrm{Gu}$ et al., 1996). Ablation of NK1positive lamina I neurons elicits a reduction in capsaicin-induced hyperalgesia in mice (Mantyh et al., 1997), indicating that these lamina I neurons are important in this modulated pain response. Projection neurons in the auditory pathway have also been shown to possess $\mathrm{Ca}^{2+}$-permeable AMPA receptors (Otis et al., 1995). It is possible that other sensory systems use these receptors on neurons projecting to higher processing centers.

Although we did not investigate the localization of $\mathrm{Ca}^{2+}$. permeable AMPA receptors in inhibitory interneurons in our study, other studies suggest that some neurons expressing $\mathrm{Ca}^{2+}$ permeable AMPA receptors in lamina II may be GABAergic. Approximately $30 \%$ of the neurons in both lamina I and lamina II are GABAergic by immunocytochemical identification (Todd and Sullivan, 1990). Recently, Spike et al. (1998) showed that $78 \%$ of GluR1-immunoreactive neurons are also GABA-positive, whereas $96 \%$ of the GluR2/3-positive neurons were negative for GABA and glycine. This suggests that GABAergic neurons express low levels of GluR2, but significant GluR1, and would therefore have $\mathrm{Ca}^{2+}$-permeable AMPA receptors. We have shown recently that $\sim 30 \%$ of neurons in dorsal horn cultures are GABAergic and that nearly $60 \%$ of those GABAergic neurons express $\mathrm{Ca}^{2+}$-permeable AMPA receptors (Albuquerque and MacDermott, 1998; C. Albuquerque, C. J. Lee, A. C. Jackson, and A. B. MacDermott, unpublished observations). These observations are consistent with the known expression of $\mathrm{Ca}^{2+}$ permeable AMPA receptors in inhibitory interneurons in other areas of the nervous system (Yin et al., 1994; Geiger et al., 1995). The observation that many of the postsynaptic dendrites in C1 glomeruli arise from GABAergic neurons (Bernardi et al., 1995) suggests that $\mathrm{Ca}^{2+}$-permeable AMPA receptors may modulate signals between primary nociceptive afferents and inhibitory interneurons.

\section{Possible role of $\mathrm{Ca}^{2+}$-permeable AMPA receptors at dorsal horn synapses}

$\mathrm{Ca}^{2+}$-permeable AMPA receptors are one example of many receptors that have a laminar distribution in the dorsal horn (for review, see Coggeshall and Carlton, 1997). This pattern may reflect laminar synaptic connections with inputs from primary afferents, descending efferents, or interneurons. The superficial dorsal horn itself has a heterogeneous distribution of neuronal cell types, even within individual laminae (Willis and Coggeshall, 1991). On the basis of our observations and those of C. Albuquerque, C. J. Lee, A. C. Jackson and A. B. MacDermott (unpublished observations) and Spike et al., (1998), we hypothesize that $\mathrm{Ca}^{2+}$-permeable AMPA receptors mediate synaptic transmission onto NK1 receptor-bearing projection neurons and onto GABAergic interneurons, where they may enhance synaptic transmission under conditions of tetanic activation as shown recently for inhibitory interneurons in the amygdala (Mahanty and Sah, 1998). Enhancement of synaptic activation of projection neurons is expected to potentiate nociceptive signaling, whereas the converse is predicted for GABAergic neurons. How these excitatory and inhibitory influences interact within the dorsal horn remains to be deciphered. Recent studies indicate that antagonism of non-NMDA receptors is antinociceptive in the tail-flick assay and reduces certain forms of inflammation-induced hyperalgesia (Lutfy et al., 1997; Szekely et al., 1997). It will be interesting to see whether the $\mathrm{Ca}^{2+}$-permeable subset of these receptors modulates pathological pain responses.

\section{REFERENCES}

Albuquerque C, MacDermott AB (1998) Selective expression of calcium-permeable AMPA receptors in subpopulations of inhibitory and excitatory dorsal horn neurons. Soc Neuroci Abstr 24:92.

Bernardi PS, Valtschanoff JG, Weinberg RJ, Schmidt HHHW, Rustioni A (1995) Synaptic interactions between primary afferent terminals and GABA and nitric oxide-synthesizing neurons in superficial laminae of the rat spinal cord. J Neurosci 15:1363-1371.

Bice TN, Beal JA (1997) Quantitative and neurogenic analysis of the total population and subpopulations of neurons defined by axon projection in the superficial dorsal horn of the rat lumbar spinal cord. J Comp Neurol 288:550-564.

Blaschke M, Keller BU, Rivosecchi R, Hollman M, Heinemann S, Konnerth A (1993) A single amino acid determines the subunit-specific spider toxin block of $\alpha$-amino-3-hydroxy-5-methylisoxazole-4-propionate/kainate receptor channels. Proc Natl Acad Sci USA 90:6528-6532.

Burnashev N, Monyer H, Seeburg PH, Sakmann B (1992) Divalent ion permeability of AMPA receptor channels is dominated by the edited form of a single subunit. Neuron 8:189-198.

Coggeshall RE, Carlton SM (1997) Receptor localization in the mammalian dorsal horn and primary afferent neurons. Brain Res Rev 24:28-66.

Coimbra A, Ribeiro-Da-Silva A, Pignatelli D (1986) Rexed's laminae and the acid phosphatase (FRAP)-band in the superficial dorsal horn of the neonatal rat spinal cord. Neurosci Lett 71:131-136.

Davis NT (1982) Improved methods for cobalt filling and silver intensification of insect motor neurons. Stain Technol 57:239-244.

Dodd J, Jessell TM (1985) Lactoseries carbohydrates specify subsets of dorsal root ganglion neurons projecting to the superficial dorsal horn of the rat spinal cord. J Neurosci 5:3278-3294.

Engelman HS, Albuquerque C, Lee CJ, Allen TB, MacDermott AB (1997) Calcium permeable AMPA receptors expressed in laminae I and II of the postnatal rat spinal cord. Soc Neurosci Abstr 23:1754.

Fitzgerald M (1983) Capsaicin and sensory neurons: a review. Pain 15:109-130.

Fitzgerald M, Butcher T, Shortland P (1994) Developmental changes in the laminar termination of A fibre cutaneous sensory afferents in the rat spinal cord dorsal horn. J Comp Neurol 348:225-233. 
Geiger JR, Melcher T, Koh D-S, Sakmann B, Seeburg PH, Jonas P, Monyer H (1995) Relative abundance of subunit mRNAs determines gating and $\mathrm{Ca}^{2+}$ permeability of AMPA receptors in principal neurons and interneurons in rat CNS. Neuron 15:193-204.

Goldstein PA, Lee CJ, MacDermott AB (1995) Variable distribution of $\mathrm{Ca}^{2+}$-permeable and $\mathrm{Ca}^{2+}$-impermeable AMPA receptors on embryonic rat dorsal horn neurons. J Neurophysiol 73:2522-2533.

Gu JG, Albuquerque C, Lee CJ, MacDermott AB (1996) Synaptic strengthening through activation of $\mathrm{Ca}^{2+}$-permeable AMPA receptors. Nature 381:793-796.

Hollmann M, Heinemann S (1994) Cloned glutamate receptors. Annu Rev Neurosci 17:31-108.

Hollmann M, Hartley M, Heinemann S (1991) $\mathrm{Ca}^{2+}$ permeability of KA-AMPA-gated glutamate receptor channels depends on subunit composition. Science 252:851-853.

Huettner JE (1990) Glutamate receptors in rat DRG neurons: activation by kainate and quisqualate and blockade of desensitization by ConA. Neuron 5:255-266.

Hume RI, Dingledine R, Heinemann SF (1991) Identification of a site in glutamate receptor subunits that controls calcium permeability. Science 253:1028-1031.

Iino M, Koike M, Isa T, Ozawa S (1996) Voltage-dependent blockage of $\mathrm{Ca}^{2+}$-permeable AMPA receptors by joro spider toxin in cultured rat hippocampal neurones. J Physiol (Lond) 496:431-437.

Jakowec MW, Fox AJ, Martin LJ, Kalb RG (1995a) Quantitative and qualitative changes in AMPA receptor expression during spinal cord development. Neuroscience 67:893-907.

Jakowec MW, Yen L, Kalb RG (1995b) In situ hybridization analysis of AMPA receptor subunit gene expression in the developing rat spinal cord. Neuroscience 67:909-920.

Jia Z, Agopyan N, Miu P, Xiong Z, Henderson J, Gerlai R, Taverna FA, Velumian A, MacDonald J, Carlen P, Abramow-Newerly W, Roder J (1996) Enhanced LTP in mice deficient in the AMPA receptor GluR2. Neuron 17:945-956.

Jonas P, Burnashev N (1995) Molecular mechanisms controlling calcium entry through AMPA-type glutamate receptor channels. Neuron 15:987-990.

Lawson SN (1992) Morphological and biochemical cell types of sensory neurons. In: Sensory neurons diversity, development and plasticity (Scott SA, ed), pp 27-59. New York: Oxford.

Lutfy K, Cai SX, Woodward RM, Weber E (1997) Antinociceptive effects of NMDA and non-NMDA receptor antagonists in the tail flick test in mice. Pain 70:31-40.

Mahanty NK, Sah P (1998) Calcium-permeable AMPA receptors mediate long-term potentiation in interneurons in the amygdala. Nature 394:683-687.

Mantyh PW, Rogers SD, Honore P, Allen BJ, Ghilardi JL, Daughters RL, Lappi DA, Wiley RG, Simone DA (1997) Inhibition of hyperalgesia by ablation of lamina I spinal neurons expressing the substance $\mathrm{P}$ receptor. Science 278:275-279.

Marshall GE, Shehab SAS, Spike RC, Todd AJ (1996) Neurokinin-1 receptors on lumbar spinothalamic neurons in the rat. Neuroscience 72:255-263.

McBain CJ, Mayer ML (1994) $N$-methyl-D-aspartic acid receptor structure and function. Physiol Rev 74:723-760.

Molliver DC, Snider WD (1997) Nerve growth factor receptor TrkA is down-regulated during postnatal development by a subset of dorsal root ganglion neurons. J Comp Neurol 381:428-438.

Molliver DC, Radeke MJ, Feinstein SC, Snider WD (1995) Presence or absence of TrkA protein distinguishes subsets of small sensory neurons with unique cytochemical characteristics and dorsal horn projections. J Comp Neurol 361:404-416.

Molliver DC, Wright DE, Leitner ML, Parsadanian AS, Doster K, Wen D, Yan Q, Snider WD (1997) IB4-binding nociceptors switch from NGF to GDNF dependence in early postnatal life. Neuron 19:849-861.

Nagy JI, Hunt SP (1982) Fluoride-resistant acid phosphatase-containing neurones in dorsal root ganglia are separate from those containing substance $\mathrm{P}$ or somatostatin. Neuroscience 7:89-97.

Nagy JI, Hunt SP, Iversen LL, Emson PC (1981) Biochemical and anatomical observations on the degeneration of peptide-containing primary afferent neurons after neonatal capsaicin. Neuroscience 6:1923-1934.

Nagy I, Pabla R, Matesz C, Dray A, Woolf CJ, Urban L (1993) Cobalt uptake enables identification of capsaicin- and bradykinin-sensitive subpopulations of rat dorsal root ganglion cells in vitro. Neuroscience 56:241-246.
Nagy I, Woolf CJ, Dray A, Urban L (1994) Cobalt accumulation in neurons expressing ionotropic excitatory amino acid receptors in young rat spinal cord: morphology and distribution. J Comp Neurol 344:321-335.

Otis TS, Raman IM, Trussell LO (1995) AMPA receptors with high $\mathrm{Ca}^{2+}$ permeability mediate synaptic transmission in the avian auditory pathway. J Physiol (Lond) 482:309-315.

Petralia RS, Wang YX, Wenthold RJ (1994) Histological and ultrastructural localization of the kainate receptor subunits, KA2 and GluR6/7, in the rat nervous system using selective antipeptide antibodies. J Comp Neurol 349:85-110.

Popratiloff A, Weinberg RJ, Rustioni A (1996) AMPA receptor subunits underlying terminals of fine-caliber primary afferent fibers. J Neurosci 16:3363-3372.

Pruss RM, Akeson RL, Racke MM, Wilburn JL (1991) Agonistactivated cobalt uptake identifies divalent cation-permeable kainate receptors on neurons and glial cells. Neuron 7:509-518.

Reichling DB, MacDermott AB (1993) Brief calcium transients evoked by glutamate receptor agonists in rat dorsal horn neurons: fast kinetics and mechanisms. J Physiol (Lond) 469:67-88.

Ribeiro-da-Silva A (1995) Substantia gelatinosa of spinal cord. In: The rat nervous system, Ed 2 (Paxinos G, ed), pp 47-59. New York: Academic.

Ribeiro-da-silva A, Coimbra A (1984) Capsaicin causes selective damage to type I synaptic glomeruli in rat substantia gelatinosa. Brain Res 290:380-383.

Spike RC, Kerr R, Maxwell DJ, Todd AJ (1998) GluR1 and GluR2/3 subunits of the AMPA-type glutamate receptor are associated with particular types of neurone in lamina I-III of the spinal dorsal horn of the rat. Eur J Neurosci 10:324-333.

Swett JE, McMahon SB, Wall PD (1985) Long ascending projections to the midbrain from cells of lamina I and nucleus of the dorsolateral funiculus of the rat spinal cord. J Comp Neurol 238:401-416.

Szallasi A, Nilsson S, Farkas-Szallasi T, Blumberg PM, Hokfelt T, Lundberg JM (1995) Vanilloid (capsaicin) receptors in the rat: distribution in the brain, regional differences in the spinal cord, axonal transport to the periphery, and depletion by systemic vanilloid treatment. Brain Res 703:175-183.

Szekely JI, Kedves R, Mate I, Torok K, Tarnawa I (1997) Apparent antinociceptive and anti-inflammatory effects of GYKI 52466. Eur J Pharmacol 336:143-154.

Tachibana M, Wenthold RJ, Morioka H, Petralia RS (1994) Light and electron microscopic immunocytochemical localization of AMPAselective glutamate receptors in the rat spinal cord. J Comp Neurol 344:431-454.

Todd AJ, Spike RC (1993) The localization of classical transmitters and neuropeptides within neurons in laminae I-III of the mammalian spinal dorsal horn. Prog Neurobiol 41:609-645.

Todd AJ, Sullivan AC (1990) Light microscope study of the coexistence of GABA-like and glycine-like immunoreactivities in the spinal cord of the rat. J Comp Neurol 296:496-505.

Tolle TR, Berthele A, Zieglgansberger W, Seeburg PH, Wisden W (1993) The differential expression of 16 NMDA and non-NMDA receptor subunits in the rat spinal cord and in periaqueductal gray. J Neurosci 13:5009-5028.

Washburn MS, Numberger M, Zhang S, Dingledine R (1997) Differential dependence on GluR2 expression of three characteristic features of AMPA receptors. J Neurosci 17:9393-9406.

Wilding TJ, Huettner JE (1995) Differential antagonism of $\alpha$-amino-3hydroxy-5-methyl-4-isoxazolepropionic acid-preferring and kainatepreferring receptors by 2,3-benzodiazepines. Mol Pharmacol 47:582-587.

Willis Jr WD, Coggeshall RE (1991) Sensory mechanisms of the spinal cord, Ed 2. New York: Plenum.

Winter J (1987) Characterization of capsaicin-sensitive neurones in adult rat dorsal root ganglion cultures. Neurosci Lett 80:134-140.

Wood JN, Winter J, James IF, Rang HP, Yeats J, Bevan S (1988) Capsaicin-induced ion fluxes in dorsal root ganglion cells in culture. J Neurosci 8:3208-3220.

Yin H, Turetsky D, Choi DW, Weiss JH (1994) Cortical neurones with $\mathrm{Ca}^{2+}$ permeable AMPA/kainate channels display distinct receptor immunoreactivity and are GABAergic. Neurobiol Dis 1:43-49.

Yoshimura M, Jessell TM (1990) Amino acid-mediated EPSPs at primary afferent synapses with substantia gelatinosa neurones in the rat spinal cord. J Physiol (Lond) 430:315-335. 